\title{
Representation of phosphorus in lake ecosystem models
}

\author{
J.-M. Thébault ${ }^{1}$
}

Keywords : phosphorus, $\mathrm{PO}_{4}$, microbial loop, lake ecosystem models.

Numeric models simulating the principal components in lake ecosystems do not, at the present time, satisfactorily describe the dynamics of the phosphorus in the water. This is primarily due to the great complexity of the exchanges that take place between the $\mathrm{PO}_{4}$ and the other mineral or organic fractions, and to the difficulty in quantifying these exchanges. Furthermore, the rapid dynamics of the exchanges involve timescales lesser than those used in the models to describe an ecosystem, which essentially use a one day step. Lastly, the analytic methods used provide a measure of forms of phosphorus which do not correspond to the functional entities simulated by the models.

This paper summarizes present general knowledge of the phosphorus cycle in the microbial loop, of what it is normally possible to measure, and what we currently know how to model.

\section{Réflexions sur la représentation du phosphore dans les mòdèles d'écosystèmes lacustres}

Mots-clés : phosphore, $\mathrm{PO}_{4}$, boucle microbienne, modèles d'écosystèmes lacustres.

Les modèles numériques simulant les principaux constituants des écosystèmes lacustres ne décrivent pas, actuellement, de façon satisfaisante la dynamique du phosphore dans l'eau. Ceci est dû principalement à la grande complexité des échanges qui ont lieu entre le $\mathrm{PO}_{4}$ et les autres fractions minérales ou organiques et à la difficulté de les quantifier. De plus, les dynamiques rapides de ces échanges ont lieu à des échelles de temps inférieures à celles utilisées dans les modèles pour décrire l'écosystème, la plupart du temps journalières. Enfin, les méthodes d'analyses fournissent une mesure des formes du phosphore qui ne correspondent pas aux entités fonctionnelles simulées par les modèles.

Cette note fait le point sur ce qui est connu d'une façon générale sur le cycle du phosphore dans la boucle microbienne, sur ce qui est usuellement possible de mesurer et sur ce qu'on sait actuellement modéliser.

\section{Introduction}

The need to manage water quality in lakes and reservoir has led to the development of numeric models to simulate the ecosystems. These models describe the components of the ecosystem and their interactions, together with seasonal evolution in thermal stratification. Generally adopting a one-day time step to describe the processes, they enable simulation of space and time variations in the ecosystem over several yearly cycles. This is the case in particular of the ASTER and MELODIA models, developed to study Pareloup reservoir (Thébault \& Salençon 1993, Salençon \& Thébault 1995a, b).

1. Laboratoire d'Hydrobiologie, Université Paul-Sabatier, ERS 103, 118, Route de Narbonne, F-31062 Toulouse Cedex.
The development of such models demands that one simplify the real system so as to choose only the preponderant components and mechanisms. The aim of presented paper is to examine the difficulties encountered in modeling phosphorus in ecosystem models. These difficulties are primarily related to :

- the lack of quantitative data to describe certain of the processes at work, for which the values are generally specific to the site being studied ;

- the difficulty in integrating rapid kinetics on the order of a few minutes, such as exchanges among the different phosphorus fractions - in a model in which processes are described on a oneday scale ;

- the methods of measurement used for periodic monitoring on the site, which do not allow for differentiating the phosphorus fractions whose role is clearly defined in the ecosystem dynamics. 


\section{Phosphorus and microbial loop}

In a lake, available phosphorus is essentially present in the form of free orthophosphate ions, represented as $\mathrm{PO}_{4}$. This ion exists in only minute quantities, but is constantly in dynamic balance with the orthophosphate of the solid chemical compounds and that adsorbed on mineral or organic particles (Berkheiser et al. 1980).

In a natural environment, the $\mathrm{PO}_{4}$ ion is absorbed by both algae and bacteria, which therefore compete for phosphorus. While bacteria are more attracted than are algae to this nutriment (Currie \& Kalff 1984), they need a carbon-containing substrate to use the phosphorus (such as the substances excreted by algae or organic debris, for example). Indeed, most bacteria are heterotrophic organisms which feed on organic substances and cannot, on their own, synthesize their constituent elements. If they lack a substrate containing carbon, they cannot utilize the $\mathrm{PO}_{4}$ absorbed, and restore it to the water where it becomes available to the algae (Jansson 1988). Algae are autotrophic organisms which, by means of photosynthesis, can build up their own organic substances from mineral elements. In the presence of high concentrations, they generally absorb more $\mathrm{PO}_{4}$ than is required for their immediate needs, storing it inside their cells : this is what is referred to as luxury consumption. They will later draw on this internal store of nutrients when concentrations in the water are lower.

It is generally accepted that it is organisms measuring between $0.2 \mu \mathrm{m}$ and $1 \mu \mathrm{m}$ which are elements of. the microbial loop (small algae, small heterotrophs, bacteria) in which phosphorus circulates very rapidly. Its dynamics are shown in figure 1 . The dissolved organic fraction of the phosphorus is due to excretion by various organisms (algae, bacteria, zooplankton, fish, etc.) and to degradation of detritus. Part of the dissolved organic phosphorus can be used by the bacteria. It can be observed in vitro that, in case of a lack of $\mathrm{PO}_{4}$, it can also be assimilated by the algae, due to phosphatases, rendering the dissolved organic phosphorus partially bioavailable (Nalewajko \& Lean 1980).

Finally, the dissolved $\mathrm{PO}_{4}$ concentration in the water is determined by a chemical balance between the different forms of phosphorus in the suspended sediment (particulate phosphorus, organic phosphorus). As organisms consume $\mathrm{PO}_{4}$, the lower concentration in the water is immediately compensated for by a displacement in this chemical balance (Peters 1979). Thus the $\mathrm{PO}_{4}$ concentration in the water remains stable, while the fluxes of phosphorus exchanged may be considerable. We might say that the different forms of phosphorus play the role of « $\mathrm{PO}_{4}$ reservoir », through chemical exchanges.

\section{Methods for measuring phosphorus}

Given these complex dynamics, the problem is to determine how, through measurement, to estimate the various phases in these states of balance. The fractional analysis widely adopted since Strickland \& Parsons (1960) first differentiates the dissolved forms from the particulate forms, by filtering raw water using a pore size of 0.4. $\mu \mathrm{m}$ (Fig. 2).

In mineral particulate form, phosphates are adsorbed on mineral substances and are essentially linked to the « clay » fraction, which has a high specific surface area.

In organic particulate form, phosphates are constituents of living particles (algae, bacteria, small heterotrophs, etc.) or detritus (feces, various types of debris, etc.).

In their dissolved form, referred to as dissolved organic phosphorus, they are generally found as free ions (dissolved $\mathrm{PO}_{4}$ orthophosphates) and as constituents of organic molecules (phospholipids, nucleic acids, phytin, etc.) or are linked to humic substances.

Filtering with a pore size of $0.45 \mu \mathrm{m}$ does not eliminate all particles, and the resulting filtrate contains bacteria, small algae (or debris) and mineral particles.

In this filtrate, the mineral phosphorus is differentiated from the organic phosphorus by its reactivity to molybdate. This differentiation is not absolute, however, as some organic fractions with a small molecular weight react partially to molybdate, whereas some hydrolyzed condensed phosphates do not. Furthermore, the method of measuring orthophosphate with the phosphomolybdate complex requires a highly acid medium, which causes the destruction of certain organic or mineral molecules which then free phosphorus. Thus molybdate reactive phosphorus gives a significant overestimation of the $\mathrm{PO}_{4}$ ion (Rigler 1966). 


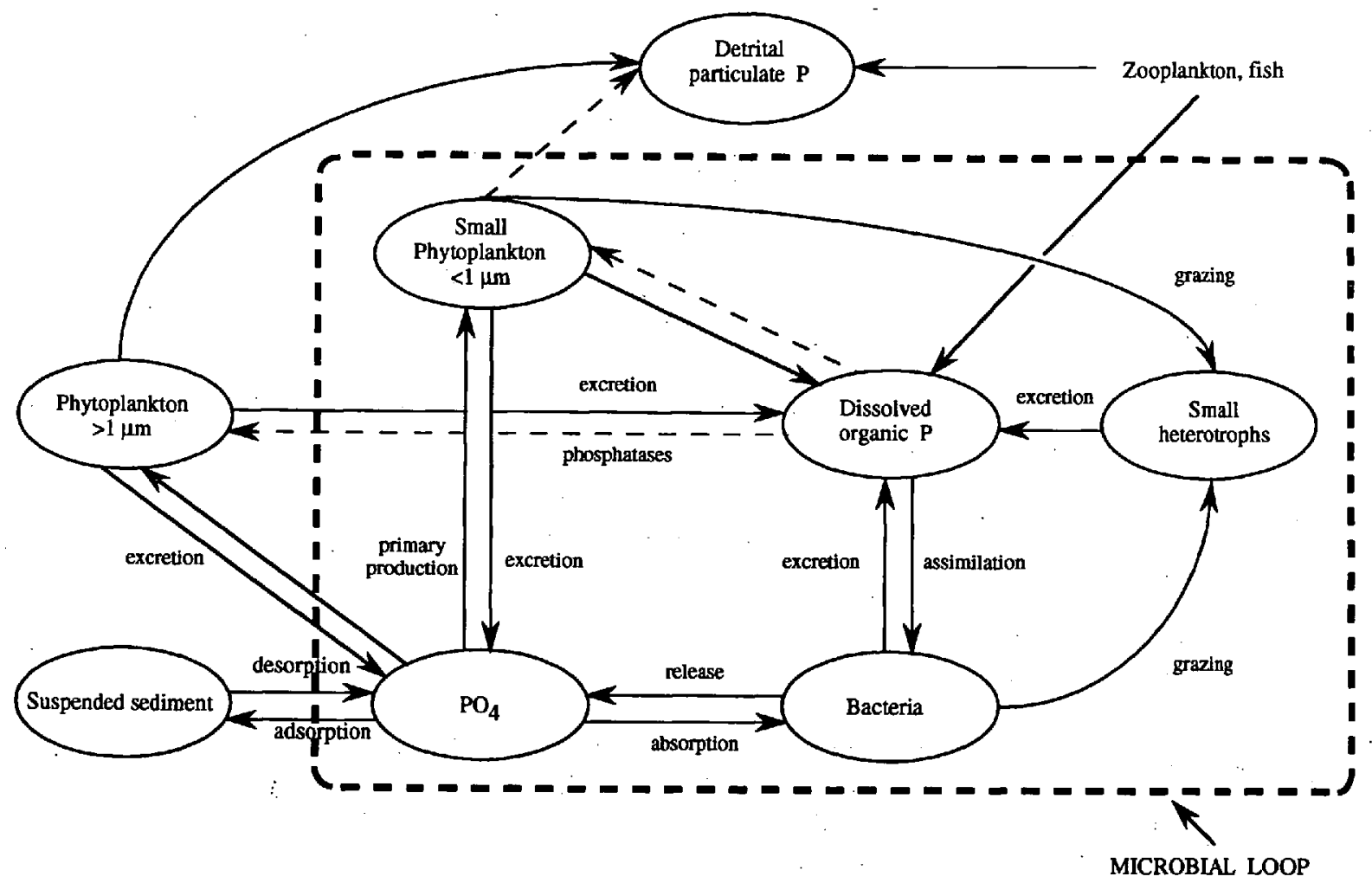

Fig. 1. Representation of the bacterial loop.

Fig. 1. Schéma de la boucle bactérienne.

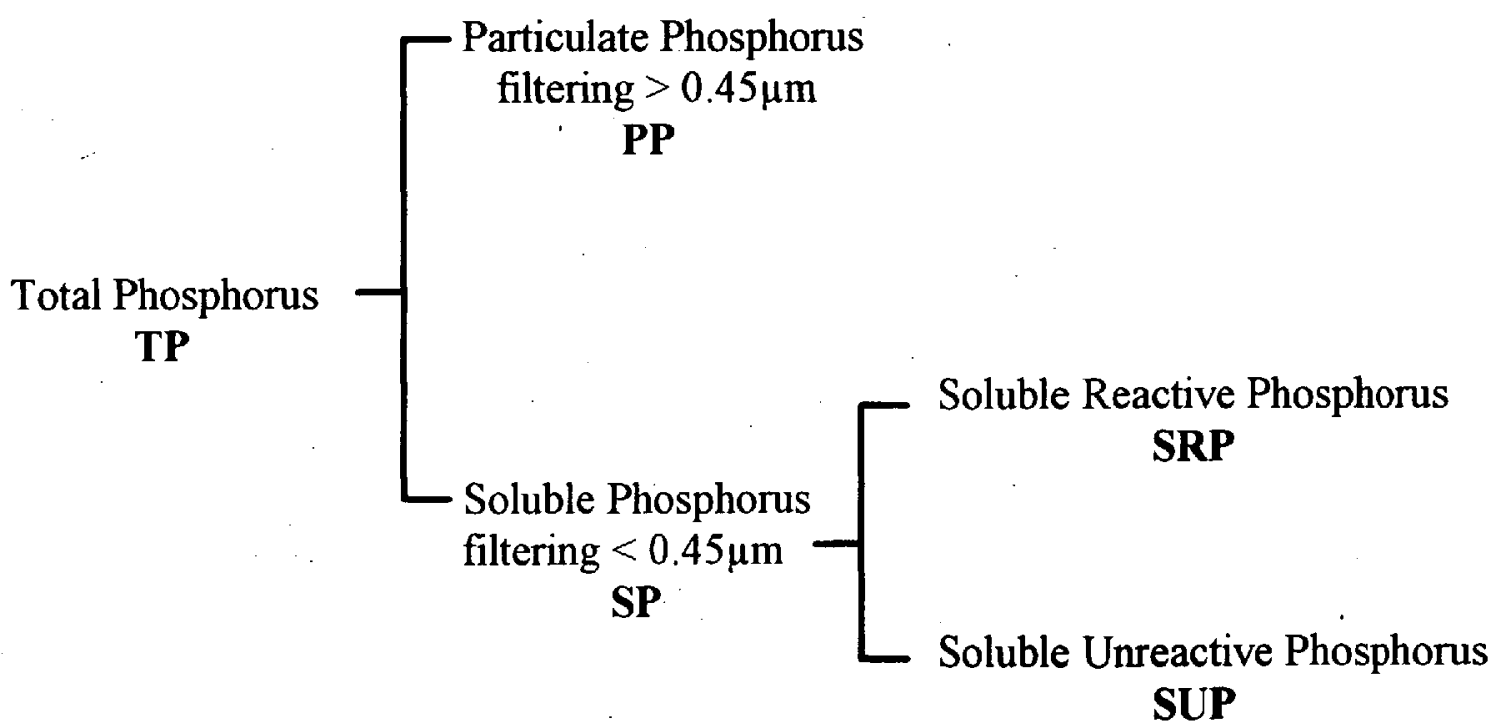

Fig. 2. Diagram showing traditional fractional analysis of phosphorus (after Rigler 1973).

Fig. 2. Diagramme correspondant au fractionnement analytique classique du phosphore (d'après Rigler 1973). 
We can consider that, given the complex dynamics governing the rapid exchanges between the different phosphorus fractions, the measured concentrations of molybdate reactive phosphorus are transient values and not representative of the actual amount of bioavailable phosphorus, and even less so of the flux of this nutrient toward living organisms (Labroue et al. 1995).

Lastly the categories we can differentiate with current measurement methods correspond, unfortunately, neither ot specific chemical compounds nor to a known bioavailability.

\section{Phosphorus in the ASTER model}

This situation does not facilitate the task of the modeler. Phosphorus must be simulated in an ecosystem model as it is indispensable to phytoplanktonic growth. Its foremost role in ecosystem models is therefore as an agent in primary production. The problem lies in the fact that such models do consider the bioavailable form of phosphorus in the trophic chain but are described on a daily scale. It is thus clear that simplifying the system for the purposes of modeling is extremely difficult.
In the ASTER model, the biological model in the complete MELODIA ecosystem management model, the only forms of phosphorus in the « nonliving $"$ fractions simulated are : the bioavailable phosphorus (called « $\mathrm{PO}_{4}$ ») and the detrital phosphorus from organic matter (dead phytoplankton and zooplankton, matter not assimilated by the zooplankton). We suppose that the bacteria responsible for mineralization of the detrital matter into dissolved $\mathrm{PO}_{4}$ are constantly effective and in sufficient quantity, but they are not explicitly simulated. Phytoplankton and detritus contribue to the bottom sediment. After mineralization, a constant flux of $\mathrm{PO}_{4}$ is released. The $« \mathrm{PO}_{4}$ » variable calculated in the model therefore represents the potentially available phosphorus, resulting from a balance between external inputs, exchanges with the sediment, degradation of detritus, excretion of plankton and assimilation by algae (Fig. 3).

In fact, in this model, all bioavailable phosphorus is found in free form in solution, whereas in reality, it is fixed to a large degree by the suspended sediment, and to a lesser degree by bacteria.

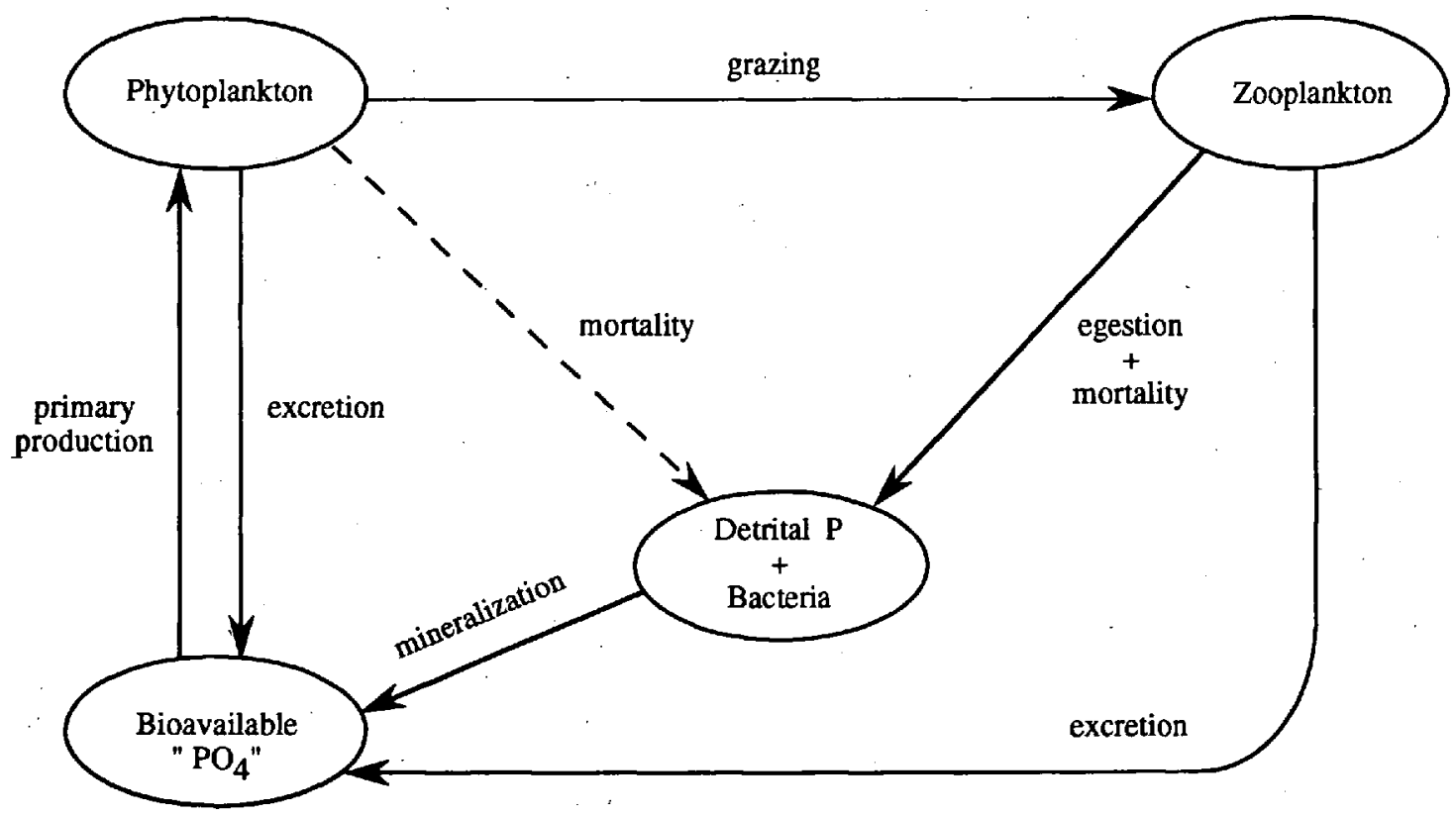

Fig. 3. Simplified representation of the dynamics of the ASTER model.

Fig. 3. Schéma simplifié du fonctionnement du modèle ASTER. 

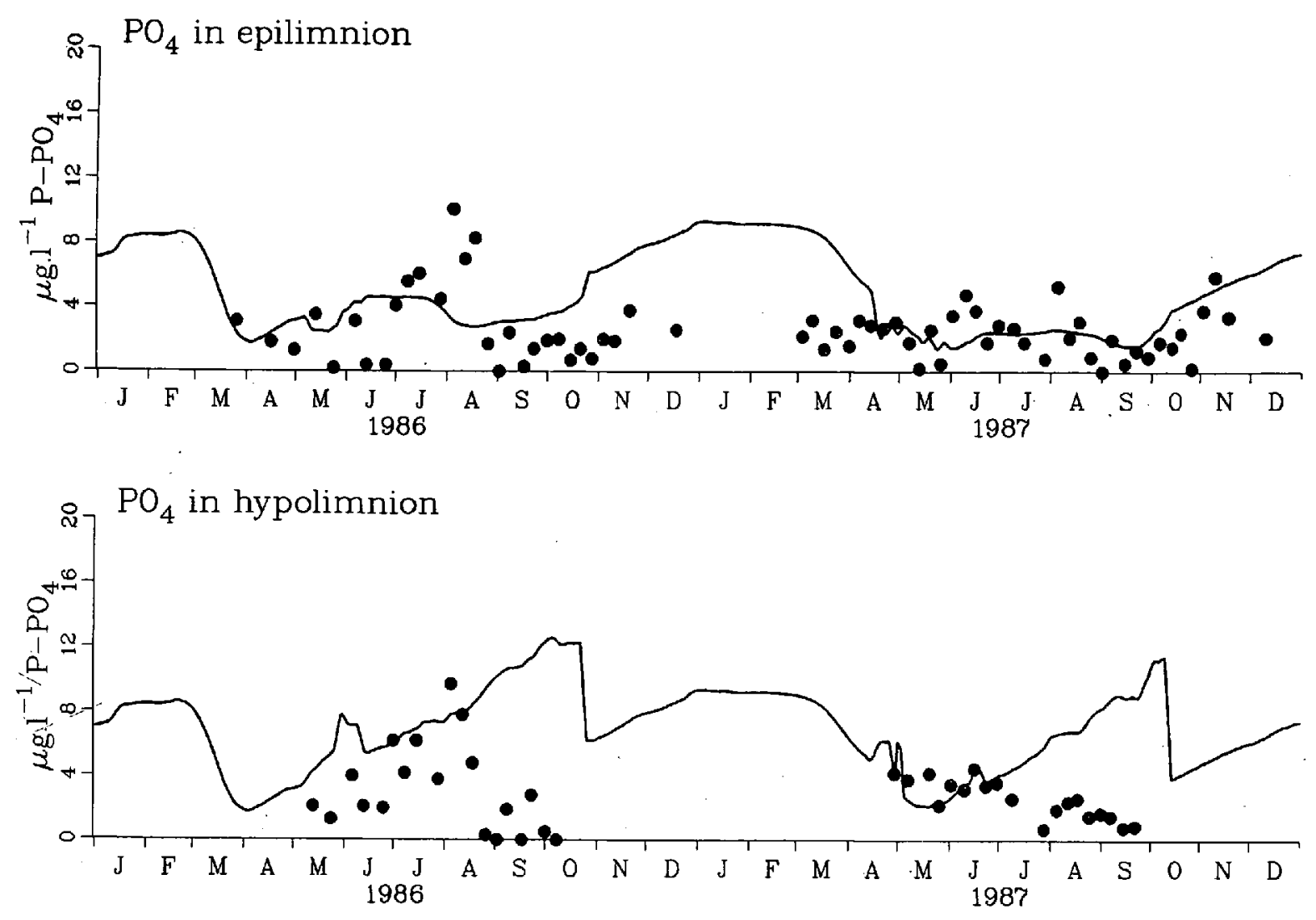

Fig. 4. Evolution of measured $\mathrm{PO}_{4}$ in the epilimnion and hypolimnion and that simulated in the MELODIA model.

Fig. 4. Evolution du $\mathrm{PO}_{4}$ mesuré et simulé dans l'épi et l'hypolimnion dans le modèle MELODIA.

This variable cannot therefore be directly compared to measured $\mathrm{PO}_{4}$ : it is subject to considerable fluctuation, dependent on the phytoplankton dynamics in the epilimnion and on inflow due to pumping in the hypolimnion, which do not appear in the measurements where the $\mathrm{PO}_{4}$ shows no clearly defined cycles (Fig. 4).

Table I recapitulates the forms of phosphorus we can measure and those taken into account in the model. It is easy to see the difficulty in comparing calculated and measured values, which are representations of two different images of a single reality.

As the model calculates the phosphorus which is really bioavailable, the absence of agreement between the calculated « $\mathrm{PO}_{4}$ » variable and the measured $\mathrm{PO}_{4}$ concentrations does not detract from its reliability. It can nonetheless be improved on in two ways :
- the processes of absorption and restitution of phosphorus by bacteria, which act as « phosphorus sponges », must be introduced. Given the qualitative and quantitative studies now being conducted on the bacterioplankton in Pareloup, such modifications should be possible in the short term.

- It would further be desirable to introduce the mechanisms of adsorption and desorption in suspended sediment, relating them to the phenomena of resuspension of sediments which faster $\mathrm{PO}_{4}-$ suspended sediment exchanges, even though the timescales for these processes are far shorter than those of ecosystem models.

While these mechanisms have already been described in the form of more or less sophisticated equations (Froelich 1988, Furamai et al. 1989, Jensen et al. 1992), they have not to our knowledge been explicitly introduced in complete ecosystem models. 
Table 1. Discrepancy between measured and modeled phosphorus fractions.

Tableau 1. Disparité entre les fractions du phosphore mesurées et modélisées.

\begin{tabular}{|c|c|c|c|c|c|c|c|}
\hline \multicolumn{4}{|c|}{ MEASUREMENTS } & & \multicolumn{3}{|c|}{ MODEL } \\
\hline $\bar{A}$ & $\mathrm{~B}$ & $\mathrm{C}$ & $\mathrm{D}$ & & $A^{\prime}$ & $\mathrm{B}^{\prime}$ & $\mathrm{C}^{\prime}$ \\
\hline & & & & $1 . \mathrm{PO}_{4}$ & & & \\
\hline & & & & 2 Dissolved organic $\mathrm{P}$ & & & \\
\hline & & & & 3 Bacteria & & & \\
\hline & & & & 4 Small phytoplankton $<1 \mu \mathrm{m}$ & - & & \\
\hline & & & & 5 small heterotrophs & & & \\
\hline & & & & 6 phytoplankton $>1 \mu \mathrm{m}$ & & & ? \\
\hline & & & & 7 Detrital particulate $\mathrm{P}$ & & $2: 18$ & \\
\hline & & & & 8 Suspended sediment & & & \\
\hline
\end{tabular}

\section{Measured phosphorus fractions}

A : Total P : sum of all phosphorus 1 to 8

B : Particulate $\mathrm{P}>0,45 \mu \mathrm{m}$ : partially 3 and 4, sum of phosphorus 5 to 8

C : Molybdate unreactive organic $P$ (assimilated to dissolved organic P) : 2 and partially 3 and 4

D : Molybdate reactive $P$ (assimilated to the $\mathrm{PO}_{4}$ ion) : 1 and partially 2,3 and 4

Variables accounted for in the model

A' : Bioavailable $\mathrm{P}$ ( $\left(\mathrm{PO}_{4}\right.$ » variable : 1 and 8

B' : Detrital $P$ : 2, 3 and 7

C' : Phytoplanktonic P : 4 and 6

\section{Conclusion}

In this paper, they were presented the difficulties encountered in representing phosphorus in ecosystem models, together with the resulting weaknesses of these models.

Taking new variables into account in such models, such as bacteria or suspended sediment, would enable better simulation of the phosphorus cycle and more accurate representation of the dynamics of phosphorus in relation to phytoplankton.

This modeling phase nonetheless requires that the processes to be modeled be better quantified with the aid of experimental studies. It is in this direction that we are currently orienting our research.

\section{References}

Berkheiser V.E., Street J.J., Rao P.S.C. \& Yuan T.L. 1980. Partitioning of inorganic orthophosphate in soil-water systems. C.R.C. Criticals Reviews in Environmental Control, 179-224.

Currie D.J. \& Kalff J. 1984. - A comparison of the abilities of freshwater algae and bacteria to acquire and retain phosphorus. Limnol. Oceanogr., $29: 298-310$.

Froelich P.N. 1988. - Kinetic control of dissolved phosphate in natural rivers and estuaries : A primer on the phosphate buffer mechanism. Limnol. Oceanogr., $33: 649-668$.

Furamai H., Kondo T. \& Ohgaki S. 1989. - Phosphorus exchange kinetics and exchangeable phosphorus forms in sediments. Water Res., 23 : 685-691.

Jansson M. 1988. - Phosphate uptake and utilization by bacteria and algae. In : G. Persson \& M. Jansson (Eds) : Phasphorus in freshwater ecosystems, Kluwer Academic Publishers, Dordrecht, reprinted from Hydrobiologia, 170 : 177-189. 
Jensen H.S., Kristensen P., Jeppesen E. \& Skytthe A. 1992. Iron : phosphorus ratio in surface sediment as an indicator of phosphate release from aerobic sediments in shallow lakes. Hydrobiologia, 235/236 : 731-743.

Labroue L., Capblancq J. \& Dauta A. 1995. - Cycle des nutriments : l'azote et le phosphore. In : Pourriot R. \& Meybeck M. (Eds) : Limnologie Générale, Masson, Paris : 727-764. Nalewajko C. \& Lean D.R.S., 1980. - Phosphorus. In : I. Morris (Ed.) : The physiological ecology of phytoplankton, Blackwell Scientific Publications, London : 235-258.

Peters F.H. 1966. - Radiobiological analysis of inorganic phosphorus in lake water. Verh. internat. Ver. Limnol., 16 : 465-470.

Rigler FH, 1973. - A dynamic view of the phosphorus cycle in lakes. In : E.J. Griffith, A. Beeton, J.M. Spencer \& D.T. Mitchell (Eds) : Environmental phosphorus handbook, J. Wiley \& Sons, NY : 539-568.
Salençon M.J. \& Thébault J.M. 1995a. - Modélisation de l'écosystème du Lac de Pareloup (Aveyron). In : Pourriot R. \& Meybeck M. (Eds) : Limnologie Générale, Masson, Paris : 765-805.

Salençon M.J. \& Thébault J.M. 1995b. - Simulation model of a mesotrophic reservoir (Lac de Pareloup) : MELODIA, an ecosystem management reservoir model. Ecol. Modelling (in press).

Strickland J.D.H. \& Parsons T.R. 1960. - A Manual of SeaWater Analysis. Bull. Fish. Res. Bd. Can., 125 : 1-185.

Thébault J.M. \& Salençon M.J. 1993. - Simulation model of a mesotrophic reservoir (Lac de Pareloup) : biological model. Ecol. Modelling, 65 : 1-30. 